\title{
Variations in the virulence, for pregnant guinea pigs, of campylobacters isolated from man
}

\author{
C. R. COID, A. M. O'SULLIVAN and C. J. DORE** \\ Divisions of Comparative Medicine and " Medical Statistics, Clinical Research Centre, Harrow, HA1 3UJ
}

\begin{abstract}
Summary. Pregnant guinea pigs were used to compare the virulence of four human isolates of Campylobacter fetus ss. fetus and four of $C$. jejuni on the basis of their ability to cause abortion and bacteraemia. Of the four strains of $C$. fetus ss. fetus two produced abortion readily after intramuscular injection. The four $C$. jejuni isolates were, however, of comparatively low virulence and no differences between them were demonstrated. Some of the isolates differed in their ability to survive in vitro in human and guinea-pig serum. It is suggested that campylobacters vary in their virulence for man and that this may influence the outcome of infections. Guinea pigs may prove useful in studying the pathogenesis of systemic campylobacter infections.
\end{abstract}

\section{Introduction}

Infections caused by organisms of the genus Campylobacter are associated with various clinical abnormalities, principally acute enterocolitis, but occasionally meningitis, abortion, arthritis, endocarditis and other systemic infections (Skirrow, 1984). Infertility and abortion are the main features of the infections in ruminant animals.

In determining the virulence of micro-organisms isolated from man there is usually no alternative to the use of laboratory animals. Few animal models are available for the study of campylobacters. Newell et al. (1985) showed, however, that isolates associated with diarrhoea in man differed from those isolated from water in their ability to colonise the intestines of infant mice and in their cytotoxic activity for HeLa cells. Moreover, abortion in pregnant guinea pigs has been used as an indicator of the pathogenicity of campylobacters from various sources (Sultan Dosa et al., 1983; Taylor and Bryner, 1984).

For the study reported here, pregnant guinea pigs were used to compare the virulence of four strains of Campylobacter fetus ss. fetus (Véron and Chatelain, 1973; referred to hereafter as $C$. fetus) and four of $C$. jejuni isolated from human patients.

\section{Materials and methods}

\section{Guinea pigs}

Guinea pigs, aged 12-15 weeks, of the Dunkin-Hartley strain were used during their sixth week (range 42-49 days) of pregnancy. The campylobacters were injected intramuscularly or intraperitoneally or were administered orally by means of a syringe without a needle.

Received 24 Apr. 1986; accepted 2 Jun. 1986.
Twelve days later, or as soon as abortion occurred, the animals were killed by exposing them gradually to an increasing concentration of carbon dioxide.

\section{Campylobacter strains}

The four C. fetus isolates were kindly supplied by $\mathrm{Dr}$ M.B. Skirrow and the four $C$. jejuni isolates by the Microbiology Department of Northwick Park Hospital. All came from human patients and were subcultured twice upon arrival at this laboratory before use. Stock cultures were maintained at $-70^{\circ} \mathrm{C}$. The $C$. fetus strains comprised: nos. 3329 and 25320 , isolated from blood; no. 23907 , from an ovarian abscess; and no. 613 , from a wound. The $C$. jejuni strains comprised: no. 42734, isolated from the watery motions of a 77-year-old female with osteomyelitis; no. 43353, from the watery motions of a 20 -year-old male; no. 39175 , from the blood-stained stool of a 30-year-old female; and no. 40630, from the blood-stained stool of a 26 -year-old male.

\section{Preparation of inocula}

Each suspension for injection was prepared by inoculating $10 \mathrm{ml}$ of Brucella Broth (Difco) with $0.1 \mathrm{ml}$ of stock culture and incubating at $37^{\circ} \mathrm{C}$ in a microaerophilic environment produced by means of a Campypack (Oxoid). After $30 \mathrm{~h}$ the broth was found to contain a median value of $10^{9} \mathrm{cfu} / \mathrm{ml}$ (interquartile range $8.4 \times 10^{8}$ to $2 \cdot 6 \times 10^{9}$ ). The bacterial suspension was then appropriately diluted in brucella broth for administration.

Estimation of the number of campylobacters in guinea-pig tissue

The method was that described by Coid and Nicholson (1981) with the modifications that the tissues were 
homogenised in brucella broth and the blood-agar plates incubated in a microaerophilic environment for $48 \mathrm{~h}$.

Bacteraemia was detected by plating blood from an ear vein on blood agar by means of a $0.01 \mathrm{ml}$ loop (Gibco).

\section{Serum}

Pooled human serum was prepared from the blood of three healthy volunteers. Complement, as assayed by lysis of antibody-sensitised erythrocytes, was within the normal limits. Pooled guinea-pig serum was prepared from three pregnant animals, which were deeply anaesthetised (Sagatal; May and Baker Ltd) before exsanguination.

\section{Serum inactivation of campylobacters}

The susceptibility of each isolate to the bactericidal activity of human and guinea-pig serum was determined as described by Johnson et al. (1978). The incubation period was $1 \mathrm{~h}$.

\section{Statistical methods}

Fisher's exact test was used.

\section{Results}

\section{Abortion and bacteraemia in infected guinea-pigs}

The table gives the results of two experiments, one in which pregnant guinea pigs received $10^{9} \mathrm{cfu}$ by the oral, intramuscular or intraperitoneal route, and the other in which $10^{5}$ cfu were given intraperitoneally.

In the animals inoculated intramuscularly, the abortifacient activity of $C$. fetus strain 23907 was significantly greater than that of strains $3329(p=0.008)$ and 613 $(p=0.01)$ but similar to that of strain 25320 . This finding was supported by the results in animals given $10^{5} \mathrm{cfu}$ intraperitoneally. Bacteraemia was detected at $24 \mathrm{~h}$ in a greater number of animals given intramuscular inocula of three C.fetus strains than in those given C. fetus strain 613

Table. Abortion and bacteraemia $24 \mathrm{~h}$ after the administration of $C$. fetus and C. jejuni to pregnant guinea pigs

\begin{tabular}{|c|c|c|c|c|c|c|c|c|}
\hline \multirow{3}{*}{$\begin{array}{l}\text { Campylobacter } \\
\text { species, strain, } \\
\text { and origin }\end{array}$} & \multicolumn{8}{|c|}{$\begin{array}{c}\text { Abortion (A) and bacteraemia (B) in groups of } \\
\text { animals given }\end{array}$} \\
\hline & \multicolumn{2}{|c|}{$\begin{array}{l}10^{9} \mathrm{cfu} \\
\text { orally }\end{array}$} & \multicolumn{2}{|c|}{$\begin{array}{l}10^{9} \mathrm{cfu} \text { intra- } \\
\text { muscularly }\end{array}$} & \multicolumn{2}{|c|}{$\begin{array}{l}10^{5} \mathrm{cfu} \\
\text { intra- } \\
\text { perito- } \\
\text { neally }\end{array}$} & \multicolumn{2}{|c|}{$\begin{array}{l}10^{9} \mathrm{cfu} \\
\text { intraper- } \\
\text { itoneally }\end{array}$} \\
\hline & A & B & A & B & A & B & A & B \\
\hline \multicolumn{9}{|l|}{ C. fetus } \\
\hline $\begin{array}{l}25320 \\
\text { Blood } \\
23907\end{array}$ & $0 / 4^{*}$ & $3 / 4$ & $5 / 9$ & $6 / 7$ & $3 / 3$ & $2 / 2$ & ND & ND \\
\hline $\begin{array}{l}\text { Ovarian } \\
\text { abscess } \\
3329\end{array}$ & $0 / 3$ & $0 / 3$ & $9 / 12$ & $8 / 12$ & $3 / 3$ & $2 / 3$ & ND & ND \\
\hline $\begin{array}{l}\text { Blood } \\
613\end{array}$ & $0 / 3$ & $0 / 3$ & $1 / 9$ & $5 / 8$ & $0 / 3$ & $1 / 3$ & $0 / 4$ & $0 / 4$ \\
\hline Wound & $0 / 3$ & $0 / 3$ & $2 / 12$ & $1 / 12$ & $0 / 3$ & $0 / 3$ & $0 / 4$ & $0 / 3$ \\
\hline \multicolumn{9}{|l|}{ C. jejuni } \\
\hline $\begin{array}{l}42734 \\
\text { Faeces } \\
43353\end{array}$ & $0 / 3$ & $0 / 3$ & $1+/ 9 *$ & $1 / 9$ & $2 / 3$ & $0 / 3$ & ND & ND \\
\hline $\begin{array}{l}\text { Faeces } \\
39175\end{array}$ & $0 / 3$ & $0 / 3$ & $1 \dagger / 9 *$ & $1 / 9$ & $2 / 3$ & $0 / 3$ & ND & ND \\
\hline $\begin{array}{l}\text { Faeces } \\
40630\end{array}$ & $0 / 3^{*}$ & $0 / 3$ & $0 / 9^{*}$ & $1 / 9$ & $0 / 3$ & $0 / 3$ & $2 / 3$ & $1 / 3$ \\
\hline Faeces & $0 / 3^{*}$ & $0 / 3$ & $0 / 9$ & $1 / 9$ & $0 / 3$ & $1 / 3$ & $1 / 3$ & $1 / 3$ \\
\hline
\end{tabular}

$\mathrm{ND}=$ Not done.

$*=$ One animal died in these groups.

$\dagger=$ Campylobacters not isolated from any tissues. 
or the four C. jejuni isolates. No difference between the four $C$. jejuni isolates was demonstrated in terms of the abortions produced by parenteral inoculation.

After the oral administration of the eight isolates, no abortions occurred, but bacteraemia was detected at $24 \mathrm{~h}$ in guinea pigs given $C$. fetus strain 25320 . In a subsequent experiment (not shown in the table), $5 \times 10^{9} \mathrm{cfu}$ of strain 25320 given orally produced abortion in two of three guinea pigs, and one of three animals given the same dose of C. fetus strain 23907 also aborted; in none of these animals was bacteraemia detected.

\section{Bacteriological examination of guinea-pig tissues}

Evidence that certain strains of $C$. fetus multiply profusely in guinea-pig tissues was shown by isolate 25320 . Thus, one placenta from a guinea pig that aborted three conceptuses after intramuscular inoculation $\left(10^{9}\right.$ cfu) contained $1.5 \times 10^{9} \mathrm{cfu}$. Moreover, one of three placentas from a guinea pig that aborted after intraperitoneal inoculation $\left(10^{5} \mathrm{cfu}\right)$ contained $7.2 \times 10^{7} \mathrm{cfu}$. Similarly, one of two aborted placentas from a guinea pig given $C$. jejuni strain $42734\left(10^{5} \mathrm{cfu}\right)$ by intraperitoneal inoculation contained $8.9 \times 10^{7} \mathrm{cfu}$.

At the end of each experiment, the liver, spleen, kidneys and gallbladder of each animal were examined for campylobacters but the numbers present were usually fewer than $10^{3} \mathrm{cfu} /$ organ. Infection of the fetus, as determined by examination of the liver, spleen and fetal stomach contents, was not a regular occurrence even when the corresponding placenta was infected.

\section{Survival of campylobacters in serum}

Human and guinea-pig serum gave similar results. $C$. fetus strains 25320 and 23907 and $C$. jejuni strain 42734 showed a survival rate in excess of $95 \%$. Survival of $<1 \%$ was shown, however, by C.fetus strains 613 and 3329 and C. jejuni strains 39175, 43353 and 40630.

\section{Discussion}

In an analysis of non-intestinal (systemic) human infections with campylobacters, Rettig (1979) observed that most patients had pre-existing debilitating disorders. Little evidence is available, however, of variations in the virulence of campylobacters that might influence the course of infections in man. The experiments described here demonstrate that different isolates of $C$. fetus from human patients can vary significantly in their virulence for guinea pigs as determined by their abortifacient activity and ability to cause bacteraemia. Virulence for experimental animals may or may not truly reflect virulence for man. No differences in virulence for guinea pigs could be demonstrated in four $C$. jejuni isolates. Both $C$. fetus and $C$. jejuni showed striking strain variations in susceptibility to the bactericidal effect of serum. The observations on $C$. jejuni are similar to those reported by Blaser et al. (1985). However, C. fetus strains used in the experiments by these workers were found to be highly serum resistant, whereas two out of four strains used in our experiments were readily killed by both human and guinea-pig serum.

Infection was established experimentally by the oral administration of two C. fetus strains. Presumably, therefore, adherence to and penetration of the gut wall, together with the ability to multiply in body tissues, are likely to play a significant role in the pathogenicity and virulence of campylobacters.

Previously, Sultan Dosa et al. (1983) demonstrated that, in pregnant guinea pigs, the virulence of campylobacters appeared to be related to their host origin. In this report, guinea pigs were shown also to be capable of demonstrating variations in the virulence of isolates from the same host. These animals seem likely to be useful in studying other aspects of the pathogenesis of campylobacter infections.

We wish to thank members of the Division of Immunological Medicine for performing the serum complement assays and Dr A.P. Johnson for helpful comments during the course of this work.

\section{REFERENCES}

Blaser M J, Smith P F, Kohler P F 1985 Susceptibility of Campylobacter isolates to the bactericidal activity of human serum. Journal of Infectious Diseases 151:227-235.

Coid C R, Nicholson J 1981 The multiplication of three different isolates of Group B streptococci in pregnant mice. Placenta 2:187-92

Johnson A P, Osborn M F, Taylor-Robinson D 1978 Ironmediated protection of Neisseria gonorrhoeae against killing by normal human serum. FEMS Microbiology Letters 4:225-227.

Newell D G, McBride H, Saunders F, Dehele Y, Pearson A D 1985 The virulence of clinical and environmental isolates of Campylobacter jejuni. Journal of Hygiene 94:45-54.

Rettig P J 1979 Campylobacter infections in human beings. Journal of Pediatrics 94:855-864.

Skirrow M B 1984 Campylobacter infections of man. In: Easmon, C S F and Jeljaszewicz, J (eds): Medical Microbiology 4. Academic Press, London p 105

Sultan Dosa A B, Bryner J H, Foley J W 1983 Pathogenicity of Campylobacter jejuni and Campylobacter coli strains in the pregnant guinea pig model. American Journal of Veterinary Research 44:2175-2178

Taylor D E, Bryner J H 1984 Plasmid content and pathogenicity of Campylobacter jejuni and Campylobacter coli strains in the pregnant guinea pig model. American Journal of Veterinary Research 45:2201-2202.

Véron M, Chatelain R 1973 Taxonomic study of the genus Campylobacter Sebald and Véron and designation of the neotype strain for the type species, Campylobacter fetus (Smith and Taylor) Sebald and Véron. International Journal of Systematic Bacteriology 23:122-134 